\title{
THE IMPLEMENTATION USING VIDEO FOR LEARNING OF SEPAK SILA TECHNIQUE
}

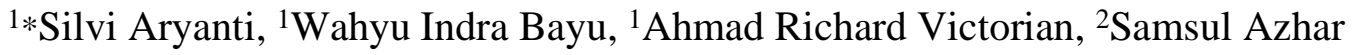 \\ Correspondence: ${ }^{1}$ Physical Education, Faculty of Teacher Training, Universitas \\ Sriwijaya, Indonesia. \\ ${ }^{2}$ Education of Elementary School Teacher, Faculty of Teacher Training, Universitas \\ Muhammadiyah Tangerang, Indonesia \\ E-mail: silviaryanti@ fkip.unsri.ac.id
}

\begin{abstract}
This study aims to determine the implementation of the use of the learning model using video in the learning of the precepts of the Sepak Takraw course. This research is research and development. The subjects of this study were students of Physical Education, Faculty of Teacher Training and Education, Universitas Sriwijaya. Small-scale product trials were conducted on 20 students, and largescale trials were carried out on 30 students. The results of small-scale trial research obtained a percentage of 64.25 with a fairly good category, and the results of largescale trials obtained a percentage of 77.51 with a good category. The results obtained indicate that the learning model using video is feasible to be used in learning the basic techniques of football in the takraw course.
\end{abstract}

Keywords: Implementation, Sepak Takraw, Learning

\section{Introduction}

Journal Physical Education, Health and Recreation

National Education System Law No. 20 of 2003 states that learning is a process of interaction between students and educators and learning resources in a learning environment. Educators in learning as a learning process to develop creative thinking are developed so that students' thinking abilities and the ability to construct new knowledge can be improved. This is an effort to increase good mastery of the subject matter.

The existing learning in the physical education study program is sepak takraw. Precepts are a basic technique in the sepak takraw game is sepak sila. Sepak sila must be well mastered which aims to make it easier for someone to control, pass the ball, receive the ball and withstand opponent attacks and services (Zulman, 2018). Kick when passing precepts using the inner foot. Sepak Sila is done to receive and control the ball while playing or in a match. Therefore, the importance of mastery in performing precepts techniques during games or matches.

PJKR

https://jurnal.unimed.ac.id/2012/index.php/jpehr 
The courses in the physical education study program of the Faculty of Teacher Training and Education, Universitas Sriwijaya is basic skills of Sepak Takraw with a weight of 2 credits. The material of sepak takraw that must be mastered by students is the basic techniques of sepak sila. The results of observations at the time of learning that students have difficulty practicing the technique of sepak sila. This is because, when doing the sepak sila technique, most students do not bend one leg and make the direction of the ball erratic, the position of the inner leg is not lifted to waist level. The mistakes made by students, an appropriate learning model is needed so that students better understand in theory the steps to carry out the precepts technique.

Based on the results of previous research on the use of video in learning, Aryanti., Victorian, and Yusfi (2018) an educator desperately needs the selection of appropriate learning techniques so that they can achieve their goals and improve learning outcomes. Fitriyati (2015) develops tutorial video media for basic techniques of martial arts for early childhood. The results of the research show that the video tutorial media is very feasible and can be used to assist learning activities. Major (2020) the findings were consistent with effective use of video as part of TPD and the use of video had an impact on classroom practice.

The urgency in this research is the implementation of the research product of the video-based football learning model. Implementation in small-scale trials and large-scale trials on students of the physical education study program at the Faculty of Teacher Training and Education, Universitas Sriwijaya.

\section{Method}

This research is a research and development. The implementation of the video-based learning model of basic soccer techniques was carried out on small and large-scale trials on students of the physical education study program, ${ }^{2}$ Faculty of Teacher Training and Education, Sriwijaya University. Small-scale trials were carried out on 20 students, and large-scale trials were carried out on 30 students. According to Arikunto (2009) The following are the eligibility categories are:

Table 1. Eligibility Categories

\begin{tabular}{|l|l|}
\hline Score in percentage & Eligibility Category \\
\hline$<40 \%$ & Not good / unworthy \\
\hline $40 \%-55 \%$ & Not Good / Not Feasible \\
\hline $56 \%-75 \%$ & Good Enough / Decent Enough \\
\hline $76 \%-100 \%$ & Good / Worth it \\
\hline
\end{tabular}

PJKR_

https://jurnal.unimed.ac.id/2012/index.php/jpehr 


\section{Result}

The purpose of a small-scale trial was to determine the level of implementation of the Basic Technique Learning Model of Sepak Sila using video for Physical Education Students, Faculty of Teacher Training and Education, Universitas Sriwijaya. Respondents for the small-scale trial were 20 students. Respondents in this study were students of physical education study programs. The questions given to respondents are as follows: The results of the study on a small scale were obtained from 20 respondents. The results of the assessment of small-scale respondents are as follows.

Table 2. Results of the assessment of small-scale respondents

\begin{tabular}{|c|c|c|c|c|c|c|c|c|c|c|c|c|}
\hline \multirow[b]{2}{*}{ No } & \multicolumn{7}{|c|}{ Statement Number } & \multicolumn{4}{|c|}{ Maximal } & \multirow[b]{2}{*}{$\%$} \\
\hline & Responden & 1 & 2 & 3 & 4 & 5 & 6 & 7 & 8 & 2 & Value & \\
\hline 1 & $\mathrm{R} 1$ & 3 & 2 & & 3 & 3 & 3 & 3 & 2 & 23 & 32 & $71 \%$ \\
\hline 2 & R2 & 3 & & & & & & 3 & & $a$ & 32 & $69 \%$ \\
\hline 3 & R3 & 2 & ? & 3 & 3 & & & 2 & & 22 & 32 & $69 \%$ \\
\hline 4 & R4 & 3 & 3 & 3 & 3 & 3 & 3 & 2 & 3 & 23 & 32 & $71 \%$ \\
\hline 5 & R5 & 2 & 2 & 3 & 3 & 2 & 2 & 3 & 2 & 19 & 32 & $59 \%$ \\
\hline 6 & R6 & 3 & 2 & 2 & 3 & 3 & 3 & 3 & 3 & 22 & 32 & $69 \%$ \\
\hline 7 & R7 & 3 & 3 & 2 & 2 & 2 & 2 & 2 & 2 & 18 & 32 & $56 \%$ \\
\hline 8 & $\mathrm{R} 8$ & 2 & 3 & 3 & 2 & 2 & 2 & 2 & 2 & 18 & 32 & $59 \%$ \\
\hline 9 & R9 & 2 & 3 & 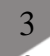 & 2 & & 3 & 3 & 2 & 21 & 32 & $66 \%$ \\
\hline 10 & R10 & 2 & & & 2 & & & 3 & 3 & 20 & 32 & $63 \%$ \\
\hline 11 & R11 & & & & ? & 2 & 3 & 3 & 2 & 22 & 32 & $69 \%$ \\
\hline 12 & R12 & 2 & 2 & 3 & 3 & 3 & 2 & 2 & 3 & 19 & 32 & $59 \%$ \\
\hline 13 & $\mathrm{R} 13$ & 2 & 2 & 3 & 3 & 3 & 2 & 3 & 2 & 20 & 32 & $63 \%$ \\
\hline $\begin{array}{l}14 \\
15\end{array}$ & $\begin{array}{c}\mathrm{rn} \text { R14 } \\
\mathrm{R} 15\end{array}$ & $\begin{array}{l}3 \\
2 \\
2\end{array}$ & 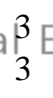 & $J$ & 3 & 2 & 2 & 3 & 2 & 20 & $\begin{array}{r}32 \\
32\end{array}$ & $\begin{array}{l}63 \% \\
63 \%\end{array}$ \\
\hline 16 & $\mathrm{R} 16$ & 3 & 2 & 3 & 3 & 2 & 3 & 3 & 3 & 22 & 32 & $69 \%$ \\
\hline 17 & R17 & 2 & 3 & 3 & 3 & 3 & 2 & 2 & 3 & 21 & 32 & $66 \%$ \\
\hline 18 & R18 & 2 & 2 & 3 & 3 & 2 & 2 & 3 & 2 & 19 & 32 & $59 \%$ \\
\hline 19 & R19 & 3 & 3 & 2 & 2 & 3 & 2 & 3 & 2 & 20 & 32 & $63 \%$ \\
\hline 20 & $\begin{array}{c}\text { R20 } \\
\text { Average }\end{array}$ & 3 & 2 & 2 & 3 & 2 & 3 & 2 & 2 & 19 & 32 & $\begin{array}{l}59 \% \\
64,25\end{array}$ \\
\hline
\end{tabular}

The test results on a small-scale research product of the Basic Technique Learning Model of Sepak sila using the Video for Physical Education Students obtained a percentage of 64.25 which is the average result of 20 respondents and has been tested. The test results that have been obtained by 64.25 are included in the "quite feasible" category to be continued at the next stage. 
Table 2. Results of the assessment of large scale test respondents

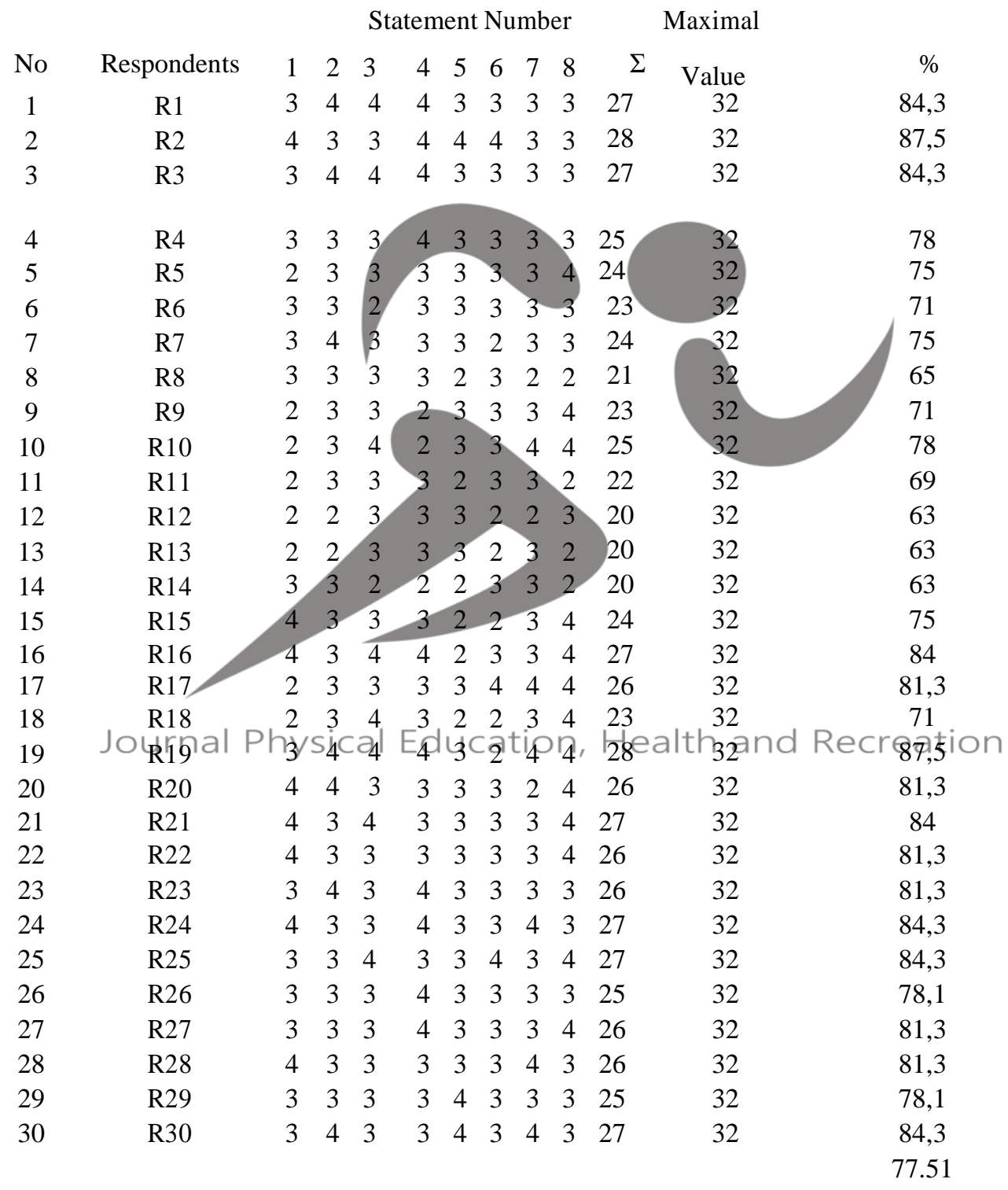

Average 
The test results on a large-scale research product of the Basic Technique Learning Model of Sepak sila using the Video for Physical Education Students obtained a percentage of 77.51which is the average result of 30 respondents and has been tested. The test results that have been obtained by 77.51 are included in the "decent" category.

\section{Discussion}

Based on the results of this study, the percentage of small-scale trial product implementation was 64.25 in the fairly good category, while the results of the largescale trial were 77.51 in the good category. So that the average percentage is 70.88 which is categorized as quite good. The application of the precepts learning model using videos can help students understand the precepts material. The video that was finished with several learning models shows the steps in carrying out the precepts technique (Sepak Sila).

The results of previous research by Sandy (2020) of the assessment of the table tennis service video tutorial by media experts in the questionnaire sheet, it is said that the table tennis service video tutorial media as a whole is very good. Aryanti, S., \& Hartati, S. (2020), the results of the small-scale trial research obtained a percentage of 63.1, the category is good enough to be continued in the next stage, namely large-scale trials. Research result large-scale trials obtained a percentage of 82.59 in good category. The research implication is that the animated video-based learning model can be used by students tolearn badminton.

\section{Conclusion}

The implementation of the use of video-based precepts learning model can help student understanding. The results of research on small-scale trials obtained a percentage of 64.25 categories that were quite feasible, and the results of research on large-scale trials obtained a percentage of 77.51 categories that were feasible. Based on the results of the trial, the average percentage of the assessment was 70.88. The research implication is that the research product is quite feasible to use.

\section{References}

Arikunto, S., 2009. Prosedur Penelitian Suatu Pendekatan Praktik. Edisi Revisi 6. Jakarta: Rineka Cipta.

Aryanti, S., Victorian, A. R., \& Yusfi, H. (2018). Pengembangan Teknik Pembelajaran Servis

Forehand Bulutangkis Bagi Siswa Putra Sekolah Menengah Atas. Sebatik, 22(2), 181-187.

PJKR_

https://jurnal.unimed.ac.id/2012/index.php/jpehr 
Aryanti, S., \& Hartati, S. (2020). Learning of Badminton Model through Animation Video on Physical Education Students.

Depdiknas .2003. Undang-undang RI No.20 tahun 2003.tentang sistem pendidikan nasional. Fitriyati, Amelia (2015) . Pengembangan Media Latihan "video tutorial teknik dasar tangkisan belandiri" untuk anak usia dini(kajian teknik taekwondo). Skripsi : FIK UNY.

Major, L., \& Watson, S. (2018). Using video to support in-service teacher professional development: the state of the field, limitations and possibilities. Technology, Pedagogy and Education, 27(1), 49-68.

Sandy, B., Tahki, K., \& Ali, N. (2020). MEDIA PEMBELAJARAN SERVIS TENIS MEJA BERBASIS VIDEO TUTORIAL PADA SISWA KELAS VII SMP NEGERI 1

KOBA. Jurnal Pendidikan Jasmani dan Adaptif, 3(01),1-7.

Zulman, F. U., Umar, A., \& Atradinal, F. U. (2018). Hubungan Keseimbangan dan Kelincahan terhadap Keterampilan Sepak Sila Pemain Sepaktakraw SMP Negeri 2 Batang Anai. Jurnal Menssana, 3(1), 77-88.

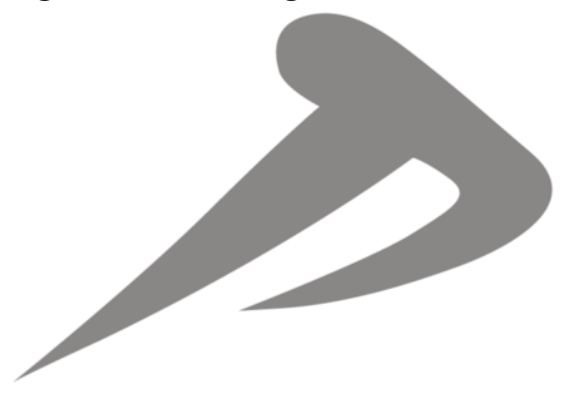

Journal Physical Education, Health and Recreation

PJKR_

https://jurnal.unimed.ac.id/2012/index.php/jpehr 